\begin{tabular}{|c|c|c|c|}
\hline & $\begin{array}{r}\text { Anna } \\
\text { http://w }\end{array}$ & $\begin{array}{l}\text { Journal } \\
\text { /index.php }\end{array}$ & 2. \\
\hline & Print ISSN : 2278-9839 & Online ISSN : 2393-9885 & 42 \\
\hline
\end{tabular}

Invited commentary

\title{
An imperceptible tale of plant viruses, phytoplasma and other pathogens
}

\author{
Abdul Samad \\ CSIR-Central Institute of Medicinal and Aromatic Plants, Lucknow-226015, Uttar Pradesh, India \\ Received April 5, 2019: Revised May 25, 2019: Accepted May 27, 2019: Published online June 30, 2019
}

Viruses affecting plants are obligate parasites but lacks molecular machinery to replicate itself. They are of different shapes, nonenveloped with a small and single stranded RNA genome other than some viruses with single stranded DNA or double-stranded DNA genomes. The plant viruses do not replicate in humans as they lack the specific receptors for recognition and entry into the host cells. Unlike animal counterparts, plant viruses are not well understood until Tobacco Mosaic Virus (TMV) was discovered. The discovery of diseases caused by plant viruses dates back to 1886 , when A. Mayer demonstrated the mosaic symptoms in tobacco leaves. Later, Martinus Beijernick (1896) coined the term 'virus' and Holmes (1939) classified 129 plant viruses, the list expanded and recognized to about 1000 grouped into 49 families and 73 genera. In 1946, Wendell Stanley received the Nobel Prize for the purification of TMV which further proved that the virus was infectious and the genetic information carried through RNA to produce infectious particles. Together with TMV, other viruses cause an estimated 60 billion dollar loss in cultivated plants each year across the globe. Normally, in plant molecular biology studies, TMV and Cauliflower Mosaic Virus (CaMV) are used, of which CaMV 35S promoter most frequently utilized in plant transformations (Roossinck, 2011; https://en.wikipedia.org/wiki/Plant_virus).

Since last 25 years at CSIR-CIMAP, we are trying to identify and characterize the infection of plant viruses on medicinal and aromatic plants in particular, Begomovirus (BV), Eclipta Yellow Vein Virus (EYVV) and Cucumber Mosaic Virus (CMV). BV is accountable for a substantial amount of economic loss to beans, cassava, cotton, squash and tomatoes (https://viralzone.expasy.org/111?outline=all_ by_species). BVs infect a wide range of plant species and are emerging as one of the most detrimental pathogens. Recombination has led to the evolution and emergence of new species of BV that are better adapted to new hosts. Our group has identified association of BV with leaf curling and stunting of Mentha arvensis (Kosi) which was found responsible for heavy economic losses in and around Lucknow, India. The virus was found to be transmitted by whitefly and complete viral genome was amplified, sequenced and assembled as $2759 \mathrm{bp}$

\footnotetext{
Author for correspondence: Dr. Abdul Samad

Acting Director and Chief Scientist, CSIR-Central Institute of Medicinal and Aromatic Plants, Lucknow-226015, Uttar Pradesh, India

E-mail: samad_cimap@yahoo.co.in

Tel.: +91-9415911805; +91-522-2718521; Fax: +91-522-2716141
}

Copyright @ 2019 Ukaaz Publications. All rights reserved.

Email: ukaaz@yahoo.com; Website: www.ukaazpublications.com long with 1376 bp $\beta$-satellite molecule. As no DNA-B amplicon was detected, the virus was classified as 'Old World Begomovirus' with the characteristic seven ORFs; two ORFs (AV1, AV2) in the V-sense and five ORFs (AC1-AC5) in the C-sense. The genomic analysis has shown highest similarity (98\%) with Chilli Leaf Curl India Virus (ChiLCINV). This was also the first report of ChiLCINV infection in M. arvensis (Kosi) from India (Saeed et al., 2017; Saeed and Samad, 2017).

In another study, our team discovered a new strain of BV infecting Andrographis paniculata and its full genome analysis revealed to be different from the two isolates of BVs reported earlier. Recombination Detection Program and SimPlot analysis showed the inter-species recombination in these BVs infecting $A$. paniculata, while no recombination was detected in the previous isolates of these viruses. The study highlights the diversity of $\mathrm{BVs}$ infecting A. paniculata in nature and also analyzes the role of recombination events responsible for the emergence of new $\mathrm{BV}$ isolates/strains. In continuation of the characterization of BVs infecting A. paniculata, our group studied the host pathogen interaction. Andrographolide and neoandrographolide are the major bioactive molecules exhibiting varying degrees of anti-inflammatory and anticancer activities. The role of $\mathrm{BV}$ protein $(\mathrm{C} 2 / \mathrm{TrAP})$ in the biosynthesis of andrographolide was identified through molecular modeling, docking studies and predicted results were also substantiated by in vitro experiments. Homology molecular modeling and molecular docking were performed to study the binding conformations and different bonding behaviors, in order to reveal the possible mechanism of action behind higher accumulation of andrographolide. It was observed that $\mathrm{C} 2 / \mathrm{TrAP}$ inhibit the activation of SNF1-Related Protein Kinase-1 (SnRK1) in terpenoid pathway and removes the negative regulation of 3-hydroxy-3-methylglutarylCoA reductase (HMGR) by SnRK1, leading to higher accumulation of andrographolide and neoandrographolide in BV infected plants. The binding site residues of SnRK1 docked with C2/TrAP were found to be associated with ATP binding site, substrate binding site and activation loop. The predicted results were also validated by HPTLC, thus providing an insight into the understanding of the role of viral protein in altering the regulation of biosynthesis of andrographolide and could be used in future research to develop biomimetic methods for increasing the production of such metabolites for medicinal use (Khan and Samad, 2014; Khan et al., 2015, Khan et al., 2016).

Further, our team pinpoints the effect of virus-induced changes in the singlet oxygen quenching due to the alteration in pigment content 
(chlorophyll and carotenoids) as well as activation of plant secondary metabolism along with defense activation leading to changes in enzymatic and non-enzymatic redox status. The infection of EYVV on A. paniculata was studied for redox-mediated alteration mechanism in infected plants. We observed that due to infection, a reduction in carotenoid content occurs which leads to reduced quenching of singlet oxygen. An increased level of enzymatic (SOD and APx) and non-enzymatic antioxidant (DPPH, FRAP, RP, NO, TAC and TP) activities were also observed in virus-infected plants with a positive correlation (>0.9). However, CAT activity was diminished which could be either due to its proteolytic degradation or inactivation by superoxide anions $\left(\mathrm{O}^{2-}.\right)$, NO or peroxynitrite radicals. A significant $(p<0.05)$ increase in total phenolic content was also observed in the infected plants while no considerable difference was seen in the total flavonoid content. The highlight include an alteration in the redox status caused by virus-induced biotic stress on the plants and could be useful for understanding the after effects of viral infection. This study could also be helpful in the production of secondary metabolites of pharmaceutical importance (Khan et al., 2016).

Being a pathogenic virus, CMV has the recognition of widest host of any known plant viruses transmitted via aphid species infecting more than 1000 plant species, comprising both ornamental and crop species. In its host, CMV can instigate awful damage leading to $10-20 \%$ of economical loss. CMV is spontaneously found in temperate areas where its vector (aphids) is also present. The presence of CMV in a plant can be confirmed by host range tests, genetic (PCR) or serological (ELISA) examination. Currently, there is not any substance competent of removing this virus from an infected plant. Thus, the best control is eradication and prevention of the infection. To accomplish this, it is vital to eliminate weeds and diseased plants from the field, as well as utilize clean and sanitized tools. Trap crops with the use of resistant varieties are other option available for use. While studying yellowing mosaic disease of African basil, our group identified infection of CMV in Ocimum gratissimum. The plant is a rich source of eugenol and is widely cultivated as a culinary perennial evergreen herb in tropical and warm temperate regions. Its essential oil has potential evidence of antibacterial, antidiabetic, antihyperlipidemic, antioxidant, and analgesic activity and reported toxicity to Leishmania species. This was for the first time association of CMV disease with O. gratissimum plant revealed by our team (Sinha and Samad, 2019).

Earlier, we reported the natural occurrence of CMV infection on periwinkle (Catharanthus roseus), having mosaic, leaf distortion and stunting symptom. The species has long been cultivated for herbal medicine and as an ornamental plant. Extracts from this plant have been used against numerous diseases including diabetes, malaria, and Hodgkin's lymphoma. Many of the alkaloids were first isolated from $C$. roseus including vinblastine and vincristine used in the treatment of leukemia and Hodgkin's lymphoma. We identified and detected CMV by TEM, Western blot immune assay and RT-PCR. The sequence analysis of the PCR product with other CMV isolates, revealed the closest identity with Rauvolfia serpentina isolate of CMV (98\%) and the phylogram revealed that CMV naturally infecting periwinkle belongs to subgroup IB (Samad et al., 2008; Khan et al., 2015).

In addition to BV, EYVV, CMV, we also characterized Peanut Mottle Virus (PMV) in groundnut plant (Arachis hypogaea). The infected plants were showing mottling, interveinal depression, and very prominent light and dark green patches on leaves. The causal agent was characterized as a strain of PMV, a member of the Potyvirus (PV) group, on the basis of its host range, mode of transmission, physical properties, and particle morphology and on the basis of its serological properties studied in comparison to other groundnut viruses. Like BVs, potyvirus also cause significant losses in agricultural, horticultural, ornamental and pastoral crops. Over 200 species of aphids distribute PVs of which, many of them are reported from Australia. The isolation of a virus from turnip (Brassica rapa L.) was also carried out in Aligarh, Uttar Pradesh, India, which caused mild mosaic, mottling and curling of leaves, followed by overall stunting of plants and characterized as Potato Virus $\mathrm{X}$ (PVX) on the basis of its host range, biological and physical properties, particle morphology, ultra structural studies, and serological relationship (Samad et al., 1991; Samad et al., 1993).

Apart from the plant viruses, our team has characterized different groups of phytoplasma and other plant pathogens that poses severe problem in agriculture sector. Discovered in 1967, phytoplasmas are obligate bacterial parasites resides in phloem tissue of plants. They lack cell wall and possess a filamentous and pleiomorphic shape with a very small genome. Phytoplasmas are mollicutes ubiquitously present in tropical and sub-tropical countries, spread by insects and inhabits plants including sugarcane, sandalwood and coconut. Phytoplasmas have been allied with diseases affecting numerous plant species together with economically important ornamental, food crops and trees (Doi et al., 1967; Chen et al., 1992). Some of the major contributions related to phytoplasma affecting medicinal and aromatic plants were reported by our group (Samad et al., 2006; Samad et al., 2011). Araucaria heterophylla (synonym A. excelsa) popularly called as Norfolk Island pine exhibited various symptoms, including yellowing, little leaf, bunchy shoots, witches broom, branch or apical proliferation, and bushy appearance. Leaves and petioles from plants with and without symptoms were collected and assayed by Transmission Electron Microscopy (TEM). The BLAST comparisons of the $16 \mathrm{~S}$ rDNA consensus sequence, submitted to GenBank (Accession No. FJ002570), showed the highest identity (96\%) with the members of group 16SrVI, 'Candidatus Phytoplasma trifolii' (Phytoplasma trifolii). The phylogenetic analysis confirmed the Araucaria little leaf phytoplasma as a ' $\mathrm{Ca}$. Phytoplasma trifolii'-related strain. This was the first record of a $16 \mathrm{SrVI}$-related phytoplasma infecting $A$. heterophylla, suggested as a possible new ' $C a$. phytoplasma' species based on sequence analysis (Gupta et al., 2010). Similarly, occurrence of a clover proliferation (16SrVI) group phytoplasma associated with little leaf disease of Portulaca grandiflora in India. P. grandiflora (commonly known as moss rose purslane) belonging to family Portulacaceae, is a popular ornamental plant widely grown in temperate climates because it blooms all summer. It is used for medicinal purposes being rich in vitamins $\mathrm{A}, \mathrm{B} 1$, and $\mathrm{C}$ and has antimicrobial and cytotoxic activity. We observed that the disease symptoms start as a typical bud proliferation, downward curling, and diminishing size of leaves, followed by overall stunted growth and yellowing of the whole plant. A comparative analysis of RFLP patterns with those derived from reference phytoplasmas tentatively identified the Portulaca Little Leaf (PLL) phytoplasma as a member of 16S rDNA RFLP group 16SrVI (Ajaykumara et al., 2007; Samad et al., 2008). 
Prior to the molecular biology era, detection and diagnosis of phytoplasma causing diseases was intricate as the organism could not be cultured. The classical techniques like symptom observation, ultrathin tissue section of phloem were studied and tetracycline was used for its prevention (Davies et al., 1968). In 1980s, molecular diagnostic techniques and ELISA based methods began to emerge for phytoplasma detection. Later in 1990s, PCR-based techniques and RFLP analysis permitted the precise identification of various phytoplasma strains and species. Recently, bioimaging and quantitative PCR effectively quantify phytoplasma titers within plant system. In addition, loop-mediated isothermal amplification (a sensitive, simple, and rapid diagnostic method) is offered as a commercial kit allowing all known phytoplasma species to be detected in about $60 \mathrm{~min}$ (Chen et al., 1992; Christensen et al., 2004). To control the infection caused by phytoplasma planting and breeding of disease-resistant varieties and management of vectors have been suggested (Lee et al., 2000). Plantibodies have been developed; cryotherapy increase the probability and tissue culture technique could be used to generate the healthy clones of infected plants (Chen and Chen, 1998). We develop an efficient protocol for reducing phytoplasma infection of Artemisia roxburghiana Besser var. purpurascens (Jacq.) Hook. plants by using apical meristem culture. The sequential hardening as hydroponic cultures under room and glasshouse conditions led to almost 85 and $98 \%$ survival of the regenerants upon transfer to pots and field, respectively. Unlike the original A. roxburghiana plants, the plants raised from tissue culture showed a total absence of inherent phytoplasma infection evaluated via inspection of morphological features, PCR and microscopic observations (Banerjee et al., 2010).

Apart from viruses and phytoplasma, medicinal and aromatic plants are frequently affected by a variety of diseases, caused by other plant pathogens including bacteria and fungi. A variety of microbes influence the pathogenic invasions on medicinal and aromatic plants and infect different parts including the aerial, foliage and underground portion. Nepeta cataria (commonly called as catnip) belonging to family Lamiaceae, is a perennial shrub distributed in Asia, Europe, and North America, is used as a medicinal herb, as well as for flavor in beverages and confectionaries. It contains $4 \mathrm{a}-$ $\alpha, 7-\alpha, 7 \mathrm{a}-\beta$-nepetalactone, which is a rich essential oil that has proven antimicrobial activity against some food-borne pathogens. Recently, we have reported first time root rot of catnip caused by Macrophomina phaseolina (Nishad et al., 2018) and new record of Uraria blossom blight caused by Colletotrichum siamense in India (Srivastava et al., 2017). Uraria picta (Prishniparni) is a perennial leguminous medicinal herb, distributed across tropical Africa and Asia, including India, Sri Lanka, and Malay Islands. The flavonoid content of $U$. picta imparts anti-inflammatory, antithrombotic, and hepatoprotective activities. C. siamense is a known pathogen having a wide host range and represents a serious threat for $U$. picta in India. Accordingly, to minimize or reduce the economic loss, it is pertinent to utilize effective means to control the pathogen (Srivastava et al., 2017). Likewise, first report of Glycyrrhiza glabra root rot and collar rot caused by binucleate Rhizoctonia (BNR) AGA from India. Glycyrrhiza glabra (licorice) belonging to Fabaceae, is cultivated as an important medicinal herb in various parts of Southeast Asia (India, China) and southern Europe (Greece, France). In India, licorice is used as traditional medicine to treat inflammations, liver diseases, throat infections. The Rhizoctonia sp AG-A has proven to be potential threat to licorice plants, resulting in the reduction of crop yield (Saroj et al., 2016). Compositional variability and antifungal potentials of Ocimum basilicum, $O$. tenuiflorum, $O$. gratissimum and $O$. kilimandscharicum essential oils against Rhizoctonia solani and Choanephora cucurbitarum has been reported. $O$. basilicum chemotypes showed variable levels of fungal growth inhibition (63.0\%-100\%). In vitro and in silico antifungal efficacy of nitrogen-doped carbon nanohorn (NCNH) against $R$. solani was investigated. This provides valuable information about the application of $\mathrm{NCNH}$ in resistance crop disease (Padalia et al., 2014; Dharni et al., 2016). A homology model of 40S ribosomal S9 protein of $R$. solani and 1-hydroxyphenazine (1-OHPHZ) and its interaction pattern was studied by molecular docking studies. 1-OH-PHZ, a natural product from Pseudomonas aeruginosa (strain SD12), was earlier reported to have potent antifungal activity against $R$. solani. Our findings reveal that 1-OHPHZ could be a potent inhibitor of 40S ribosomal S9 protein of $R$. solani which might be a promising approach for the management of fungal diseases (Dharni et al., 2014). A root rot and wilt disease of pyrethrum (Chrysanthemum cineraefolium synonymous Tanacetum cinerariifolium) caused by $R$. solani AG-4 has been recorded in the northern plains of India (Alam et al., 2006). Withania somnifera, a natural rich source of withanolides and commercially cultivated for its roots has been found to be infected with black leaf spot mould (Pseudocercospora fuligena, Saroj et al., 2014). However, Syzygium cumini essential oil, hydrocarbon fractions and its novel constituents, ocimene have been found to be used as a potential antifungal agent for the effective control of fungal diseases in medicinal and aromatic plants (Saroj et al., 2015).

In recent past, the demand of medicinal and aromatic plants has increased due to their great demand for aroma compounds and global trade in the production of agrichemicals and plant based drugs. Plant viruses, phytoplasmas and other pathogens have been known to infect a wide range of agricultural commodities including medicinal and aromatic plants, ornamental plants, vegetables and agriculture crops with a huge economic loss affecting common people. In spite of enormous progress in diagnostics and treatment procedures, the invasion of plant pathogens is a key encumbrance in deriving high quality raw material and products. Besides, the varying environmental condition, reappearance of diseases is anticipated to speed up which could not be eradicated wholly. The development of novel system for identification, detection and monitoring can play a critical role in efficient disease prevention and management. The contemporary research work on plant viruses, phytoplasmas and other pathogens affecting medicinal and aromatic plants provides diverse traditional and advanced strategies for the management of both vectors and pathogens. However, all these operation needs focused efforts, deep insight and intensive future investigation.

Keeping in view the ever increasing amount of awesome research work to be carried out in the development of phytomedicines and conventional medicines from plants, a matching increase in the number of good quality, reputed journals is a requirement. In this context, the emergence of "Annals of Phytomedicine: An International Journal" is timely and with a commitment to excellence 
in publishing cutting edge research in all areas of phytomedicine is a welcome arrival. Phytomedicine is truly a multidisciplinary area, encompassing several disciplines. It is a challenging job to run such a journal successfully. I am very happy to note that Annals of Phytomedicine: An International Journal is already, with certainty, on its way towards accomplishing its mission and reaching to its zenith.

\section{Acknowledgements}

Author is grateful to the staff and scholars of Plant Pathology Department, CSIR-Central Institute of Medicinal and Aromatic Plants, Lucknow for their valuable research contribution in identifying, characterizing and detecting plant pathogens affecting medicinal and aromatic plants. I am also indebted to Dr. Akhtar Hussain, Founder Director, CSIR-CIMAP for initiating the plant pathology work at the Institute.

\section{Conflict of interest}

I declare that no conflict of interest exists in the course of conducting this research. I had final decision regarding the manuscript and the decision to submit the findings for publication.

\section{References}

Ajayakumar, P.V.; Samad, A.; Shasany,A.K.; Gupta, M.K.; Alam, M. and Rastogi, S. (2007). First record of a candidatus phytoplasma associated with little leaf disease of Portulaca grandiflora. Australasian Plant Disease Notes, 2:67-69.

Alam, M.; Sattar, A.; Khaliq, A.; Samad, A. and Khanuja, S.P.S. (2006). A roo rot and wilt disease of Pyrethrum (Chrysanthemum cineraefolium) caused by Rhizoctonia solani AG-4 in the north Indian plains. Plant Pathology, 55:301.

Banerjee, S.; Haider, F.; Bagchi, G.D. and Samad, A. (2010). Regeneration of phytoplasma-free Artemisia roxburghiana Besser var. purpurascens (Jacq.) Hook. plants using apical meristem culture. Plant Cell Tissue and Organ Culture, 103:189-196.

Chen, Y.D. and Chen, T.A. (1992). Detection and identification of plant and insect mollicutes. The Mycoplasmas, 5:393-424.

Chen, Y.D. and Chen, T.A. (1998). Expression of engineered antibodies in plants: A possible tool for spiroplasma and phytoplasma disease control. Phytopathology, 88(12):1367-1371.

Christensen, N.; Axelsen, K.; Nicolaisen, M. and Schulz, A. (2005). Phytoplasmas and their interactions with their hosts. Trends in Plant Science, 10(11):526-535.

Christensen, N.M.; Nicolaisen, M.; Hansen, M. and Schulz, A. (2004). Distribution of phytoplasmas in infected plants as revealed by real time PCR and bioimaging. Molecular Plant-Microbe Interactions, 17(11): $1175-1184$

Davies, R.E.; Whitcomb, R.F. and Steere, R.L. (1968). Remission of aster yellows disease by antibiotics. Science, 161(3843):793-794.

Dharni, S.; Sanchita.; Samad, A.; Sharma, A. and Patra, D.D. (2014). The interaction pattern between a homology model of $40 \mathrm{~S}$ ribosomal S9 protein of Rhizoctonia solani and 1-Hydroxyphenaize by docking study. BioMed. Research International, Article ID 682946, pp:6.

Dharni, S.; Sanchita; Sree Kuttan, M.; Unnic, Sreekumar, K.; Samad A.; Sharma, A. and Patra, D.D. (2016). In vitro and in silico antifungal efficacy of nitrogen-doped carbon nanohorn $(\mathrm{NCNH})$ against Rhizoctonia solani. Journal of Biomolecular Structure and Dynamics, 34(1): 152-162.

Doi, Y.; Teranaka, M.; Yora, K. and Asuyama, H. (1967). Mycoplasma or PLTgroup-like organisms found in the phloem elements of plants infected with mulberry dwarf, potato witches' broom, aster yellows or paulownia witches' broom. Annals of the Phytopathological Society of Japan, 33(4):259-266.

Gupta, M.K.; Samad, A.; Shasany, A.K.; Ajayakumar, P.V. and Alam, M. (2010). First report of a 16SrVI 'Candidatus Phytoplasma trifolii' isolates infecting Norfolk Island pine (Araucaria heterophylla) in India. Plant Pathology, 59:399.

Khan, A.; Sharma, P.; Khan, F.; Ajayakumar, P.V.; Shanker, K. and Samad A. (2016). In silico and in vitro studies on begomovirus induced andrographolide biosynthesis pathway in Andrographis paniculata for combating inflammation and cancer. Molecular Informatics, 35:253-261.

Khan, A. and Samad, A. (2014). A new isolate of eclipta yellow vein virus along with a betasatellite associated with yellow vein leaf curl disease of Andrographis paniculata in India. Plant Disease, 98: 698-698.

Khan, A.; Luqman, S.; Masood, N.; Singh, D.K.; Saeed, S.T. and Samad,A. (2016). Eclipta yellow vein virus enhances chlorophyll destruction, singlet oxygen production and alters endogenous redox status in Andrographis paniculata. Plant Physiology and Biochemistry, 104:165-173.

Khan, A.; Saeed, S.T. and Samad, A. (2015). New record of Catharanthus yellow mosaic virus and a betasatellite associated with lethal leaf yellowing of Kalmegh (Andrographis paniculata) in Northern India. Plant Disease, 99:292-292.

Khan, Asifa and Samad, A. (2016). Molecular and biological characterization of begomoviruses infecting Andrographis paniculata and their genetic recombination lineage. European Journal of Plant Pathology, 146(1):177-189.

Lee, I.M.; Davis, R.E. and Gundersen-Rindal, D.E. (2000). Phytoplasma: phytopathogenic mollicutes. Annual Review of Microbiology, 54:221-255.

Nishad, I.; Srivastava, A.K.; Saroj, A.; Babu, B.K. and Samad, A. (2018). First report of root rot of Nepeta cataria caused by Macrophomina phaseolina in India. Plant Disease, 102:2380.

Padalia, R.C.; Verma, R.S.; Chauhan, A.; Goswami, P.; Chanotiya, C.S.; Saroj, A.; Samad, A. and Khaliq, A. (2014). Compositional variability and antifungal potentials of Ocimum basilicum, O. enuiflorum, $O$. gratissimum and $O$. kilimandscharicum essential oils against Rhizoctonia solani and Choanephora cucurbitarum. Natural Product Communication, 9:1507-1550.

Roossinck, M.J. (2011). The good viruses: Viral mutualistic symbioses. Nature Reviews Microbiology, 9(2):99-108.

Saeed, S.T.; Kumar, B.K.; Shasany, A.K. and Samad, A. (2017). Molecular identification of chilli leaf curl virus along with betasatellite molecule causing leaf curl disease of menthol mint (var. Kosi) in India. Journal of General Plant Pathology, 83:333-336.

Saeed, S.T. and Samad, A. (2017). Emerging threats of begomoviruses to the cultivation of medicinal and aromatic crops and their management strategies. Virus Disease, 28(1):1-17.

Samad, A.; Ajayakumar, P.V., Shasany, A.K.; Gupta, M.K.; Alam, M. and Rastogi, S. (2008). Occurrence of a clover proliferation (16SrVI) group phytoplasma associated with little leaf disease of Portulaca grandiflora in India. Plant Disease, 92:832.

Samad, A.; Dharni, S.; Singh, M.; Yadav, S.; Khan, A. and Shukla, A.K. (2011). First report of a natural infection of Stevia rebaudiana by a group 16SrXXIV phytoplasma in India. Plant Disease, 95(12): 1582 .

Samad,A.; Shasany,A.K.; Gupta, S.; Ajayakuar, P.V.; Darokar, M.P. and Khanuja, S.P.S. (2006). First report of a $16 \mathrm{SrVI}$ group phytoplasma associated with witches'-broom disease on Withania somnifera. Plant Disease, 90:248-248. 
Samad,A.; Ajayakumar, P.V.; Gupta, M.K.; Shukla,A.K.; Darokar, M.P.; Somkuwar B. and Alam, M. (2008). Natural infection of periwinkle (Catharanthus roseus) with cucumber mosaic virus, Subgroup IB. Australasian Plant Disease Notes, 3:30-34.

Samad, A.; Naqvi, Q.A.; Garg, I.D. and Thouvenel, J.C. (1991). Potato virus X: A new report from turnip (Brassica rapa L.) in India. Phytopathology Z., 133:65-75.

Samad, A.; Thouvenel, J.C. and Dubern, J. (1993). Characterizatioin of peanut mottle virus in Cote d' Ivoire. Phytopathology Z., 139:10-16.

Saroj, A.; Kumar, A.; Srivastava, A.K.; Khaliq, A.; Nilofer; Alam, M. and Samad, A. (2014). New report of black leaf spot mould (Pseudocercospora fuligena) on Withania somnifera from India. Plant Disease, 98: 1277.
Saroj, A.; Pragadheesh, V.S.; Palanivelu; Yadav, A.; Singh, S.C.; Samad A.; Negi, A.S. and Chanotiya, C.S. (2015). Anti-phytopathogenic activity of Syzygium cumini essential oil, hydrocarbon fractions and its novel constituents. Industrial Crops and Products, 74:327-335.

Saroj, A.; Maurya, R.; Srivastava, A.K.; Samad, A. and Chanotiya C.S. (2016). First report of Glycyrrhiza glabra root rot and collar rot caused by Binucleate rhizoctonia (BNR) AG-A from India. Plant Disease, 100(8): 1782 .

Sinha, S. and Samad, A. (2019). First report of cucumber mosaic virus associated with yellowing mosaic disease of African basil (Ocimum gratissimum) in India. Plant Disease, 103:167.

Srivastava, A.K.; Saroj, A.; Kumar, A.; Khaliq, A.; Kumar Birendra.; Singh, S.C. and Samad, A. (2017). New record of Uraria blossom blight caused by Colletotrichum siamense in India. Plant Disease, 101:836.

Citation: Abdul Samad (2019). An imperceptible tale of plant viruses, phytoplasma and other pathogens. Ann. Phytomed., 8(1):1-6. 


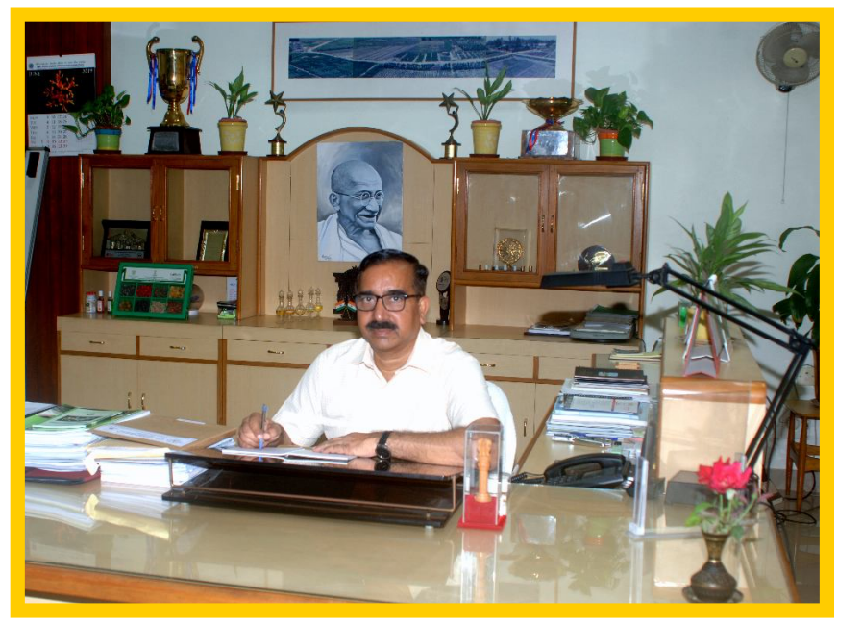

Dr. ABDUL SAMAD

Acting Director and Chief Scientist at CSIR-Central Institute of Medicinal and Aromatic Plants, Lucknow-226015, Uttar Pradesh, India

\section{Biography}

Dr. Abdul Samad has completed his M.Sc., M.Phil. and Ph.D degree from Aligarh Muslim University, India and Postdoctoral studies from ORSTOM/IIRSDA (CIES-Fellow), France. He is presently officiating as an Acting Director of CSIR-Central Institute of Medicinal and Aromatic Plants, Lucknow.

His research work and skills are focused on understanding the molecular, epidemiological and diversity analysis of plant virus (es) of Medicinal and Aromatic Plants (MAPs) towards the development of diagnostics for better management and effective treatment. With plant molecular virology expertise and advanced training in biological and molecular characterization of plant viruses, Dr. Samad's group at CSIR-CIMAP is actively involved in exploring the plant virus diagnostics since last 25 years. The work involves identifying, characterizing and developing diagnostic tools for plant viruses applying modern biological tools and techniques. $\mathrm{He}$ is experienced in biological, serological and molecular identification of viruses affecting medicinal, ornamental and other commercially important crops. His group has opened up new paradigms for molecular identification of phytoplasma infecting crop and non-crop species. Currently, his laboratory work related to the molecular biology of RNA and DNA based plant viral genomes, identification of various genes and determination of their functions and RNAi mediated gene silencing is going on for the management of pathogenic viruses of MAPs. He has elegantly demonstrated the significance of diagnostic systems such as ISEM, ELISA, Western blot immunoassay, Nucleic acid spot hybridization (NASH) tests and RT-PCR/PCR for reliable detection of viruses and phytoplasma infecting crop plants. His research work received funding from the Department of Biotechnology, Department of Science and Technology, Government of India and National Medicinal Plant Board.

He is a recipient of CSIR Technology Award (1999) in Biological Sciences for the development of superior menthol mint (Mentha arvensis L.) varieties, Himalaya and Kosi and has published more than 80 papers in peer-reviewed journals, 1 book chapter in addition to 3 International patents and 3 plant varieties to his credit. $\mathrm{He}$ is one the member of the Management Council of CSIR-CIMAP and Advisory Committee of the Institute. He also served as honorary reviewer for the specialized journals including Plant Disease, PLOS One, 3 Biotech, Plant Pathology and several national journals. Dr Samad supervised $6 \mathrm{Ph}$ D scholars of which, 4 have been awarded their degree and 2 are ready for submission.

Dr. Samad is the Life member of renowned societies including The National Academy of Sciences, Indian Virological Society, Indian Phytopathological Society, The Indian Science Congress Association, Association of Plant Pathologists of India, Society of Mycology and Plant Pathology and Member of American Phytopathological Society, USA. 